\title{
A Mosquito Culex cedecei Stone and Hair (Insecta: Diptera: Culicidae) ${ }^{1}$
}

\author{
Kristin E. Sloyer and Nathan D. Burkett-Cadena²
}

The Featured Creatures collection provides in-depth profiles of insects, nematodes, arachnids and other organisms relevant to Florida. These profiles are intended for the use of interested laypersons with some knowledge of biology as well as academic audiences.

\section{Introduction}

Culex cedecei is a mosquito endemic to Florida, and a member of the Spissipes section of the subgenus Melanoconion of Culex. Several members of the Spissipes section are important vectors of enzootic subtypes of Venezuelan equine encephalitis virus (VEEV). Everglades virus (EVEV) is subtype II of VEEV in Florida, for which Culex cedecei is the primary enzootic vector. Culex cedecei is typically found in forested wetlands of southern Florida, ranging from mangrove swamps to hardwood hammocks and lowland pine ecosystems (Hoyer et al., 2019). Larvae of Culex cedecei develop in limestone solution holes, and abandoned crab burrows in a variety of habitats. Although Culex cedecei is not generally considered a pest of humans, it feeds primarily on muroid rodents (rats and mice), which are important hosts of EVEV in Florida. Culex cedecei is therefore considered a vector of a zoonotic pathogen that can affect human health.

\section{Synonymy}

Culex opisthopus Komp, 1926

Culex taeniopus Dyar and Knab, 1907

Culex annulipes Belkin, 1969

\section{Taxonomy}

The taxonomic history of Culex cedecei is complicated, and at various times, Culex cedecei has been considered a synonym of Culex annulipes (Pratt et al. 1945), Culex opisthopus (Pratt et al. 1945), and Culex taeniopus (Sirivanakarn and Belkin 1980). Culex cedecei, Culex taeniopus, Culex akritos, and Culex ikelos are members of the Taeniopus group in the Spissipes section of the subgenus Melanoconion (Sallum and Forattini, 1996). Stone and Hair (1968) originally proposed the name Culex cedecei for all Florida populations of Culex opisthopus, citing a lack of pale bands on the tarsi in Florida populations. However, Sirivanakarn and Belkin synonymized Culex opisthopus with Culex taeniopus in 1980, shortly before Dziem and Cupp (1983) restored the name Culex cedecei to Florida populations. This decision was based upon cross-mating studies which revealed difficulty in mating between Florida populations and Guatemalan Culex taeniopus populations, indicating that the different populations were different species.

1. This document is EENY-778 one of a series of the Entomology and Nematology Department, UF/IFAS Extension. Original publication date September 2021. Visit the EDIS website at https://edis.ifas.ufl.edu for the currently supported version of this publication. This document is also available on the Featured Creatures website at http://entnemdept.ifas.ufl.edu/creatures/.

2. Kristin Elizabeth Sloyer, graduate research assistant, and Nathan Daniel Burkett-Cadena, associate professor, mosquito ecology and biology of disease hosts, UF/IFAS Florida Medical Entomology Laboratory in Vero Beach, FL 32962.

The Institute of Food and Agricultural Sciences (IFAS) is an Equal Opportunity Institution authorized to provide research, educational information and other services

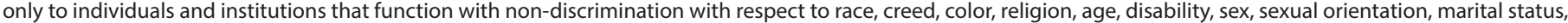

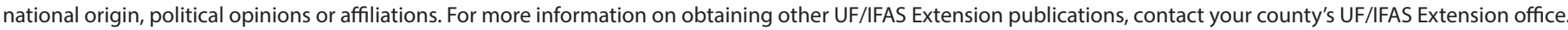
U.S. Department of Agriculture, UF/IFAS Extension Service, University of Florida, IFAS, Florida A \& M University Cooperative Extension Program, and Boards of County Commissioners Cooperating. Andra Johnson, dean for UF/IFAS Extension. 


\section{Distribution}

Culex cedecei is only known to occur in Florida, particularly the southern half of the Florida peninsula. It is reported from fifteen counties in Florida, including Orange, Polk, Brevard, Indian River, St. Lucie, Martin, Palm Beach, Broward, Miami-Dade, Monroe, Collier, Lee, Charlotte, Sarasota, and Manatee Counties (Figure 1) (West et al., 2020; Darsie and Morris, 2005).

\section{Habitat}

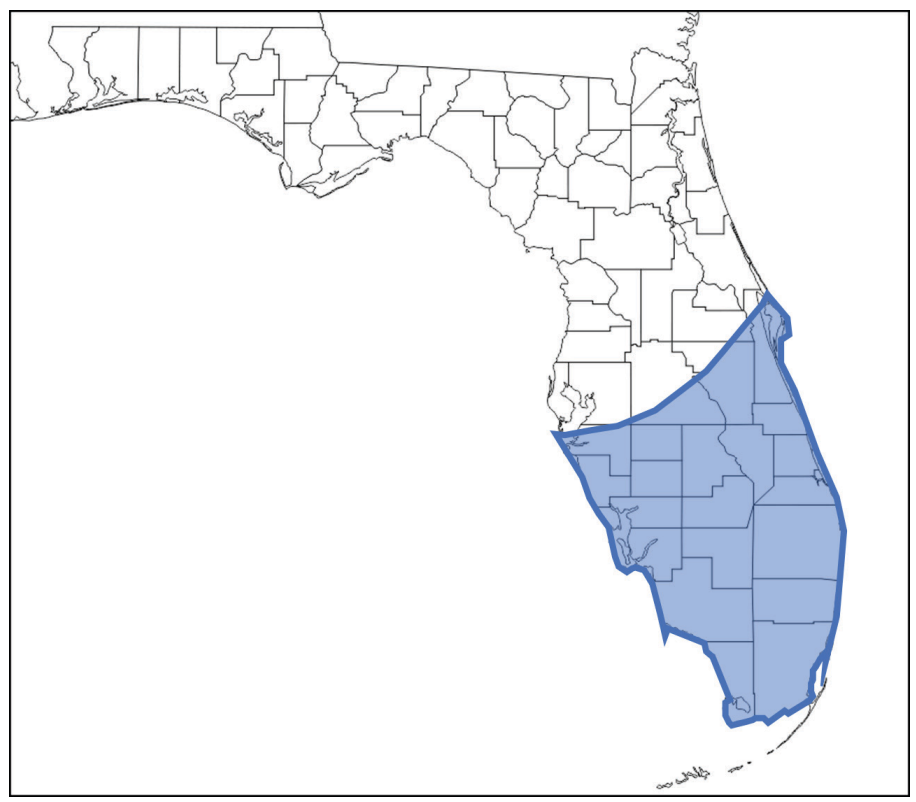

Figure 1. Map of Florida, USA, indicating the approximate distribution of Culex cedecei, according to Darsie and Ward (2005).

Culex cedecei can be found in a variety of habitats in South Florida but is most commonly found in various forested wetland habitats, including hardwood hammock, mangrove swamp and pine lowlands (Hoyer et al., 2019). Larvae are aquatic and have been described from limestone solution holes, abandoned crab burrows, and hollowed out treestumps (Pratt et al., 1945).

\section{Description}

\section{Eggs}

Eggs of Culex cedecei are laid together in rafts either on the surface of water or on the sides of containers (Blosser and Burkett-Cadena, 2017) and have been observed containing from 22-147 eggs per raft in laboratory colonies (Dziem and Cupp, 1983). Shape of the rafts vary but have most commonly been described as hexagonal or oval in shape (Figure 3). Eggs of Culex cedecei, and other mosquitoes, are white when newly laid and turn black once sclerotized
(Figure 3), typically 1-2 hours after being laid. Eggs of Culex cedecei hatch 1-2 days after being laid.
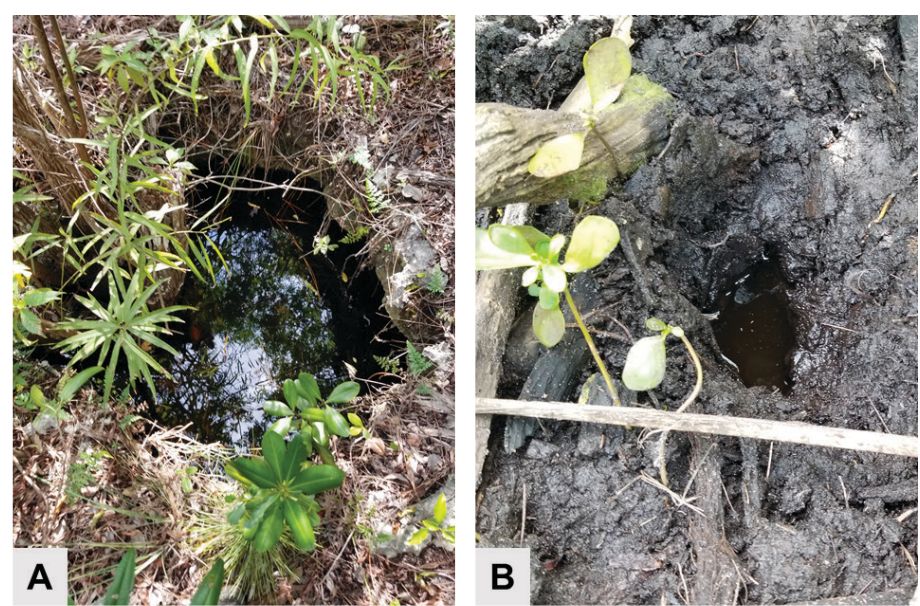

Figure 2. Limestone solution holes (A) and abandoned land crab burrows (B) are reported habitats of the larvae of Culex cedecei. Credits: Kristin Sloyer, UF/IFAS

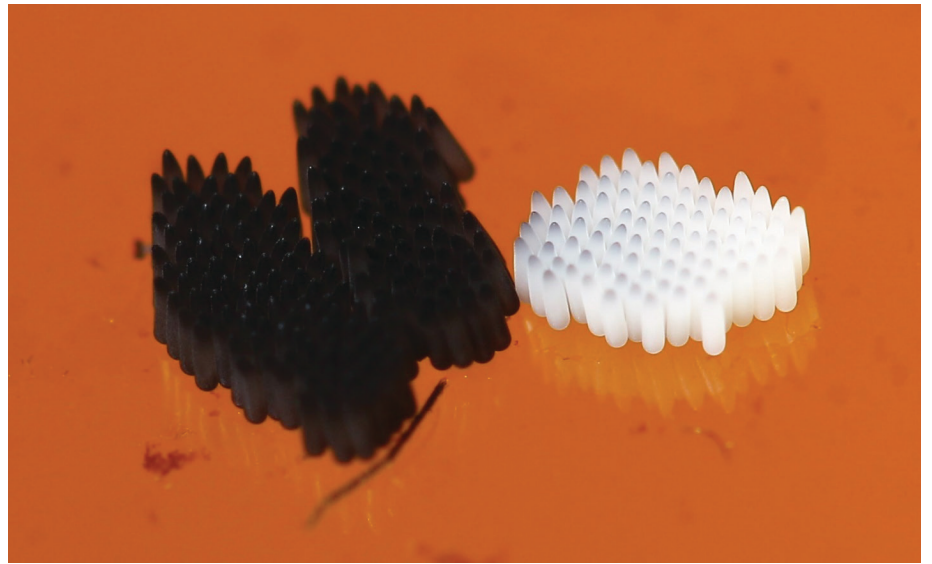

Figure 3. Three egg rafts of Culex cedecei Stone and Hair. The two black rafts have sclerotized whereas the white raft was laid more recently and is not yet sclerotized.

Credits: Kristin Sloyer, UF/IFAS

\section{Larvae}

Larvae of Culex cedecei are small and typically dark brown in color (Figure 4). The head is wider than it is long and seta 6-C is unbranched or with two branches (Figure 5). The antennae of Culex cedecei larvae are entirely dark in color, a feature that is unique among members of the subgenus Melanoconion in Florida (Figure 4, 5). Seta 7-I is double, which is a useful distinguishing feature of this species. On abdominal segment VIII, all comb scales are more or less evenly fringed with subequal spinules (Darsie and Ward, 2005). The respiratory siphon of Culex cedecei is long and thin, more than seven times longer than it is wide and contains five tufts of short setae (Darsie and Ward, 2005). Finally, on segment $\mathrm{X}$, the saddle is not aciculate (having irregular streaks and scratches) (Darsie and Ward, 2005). 


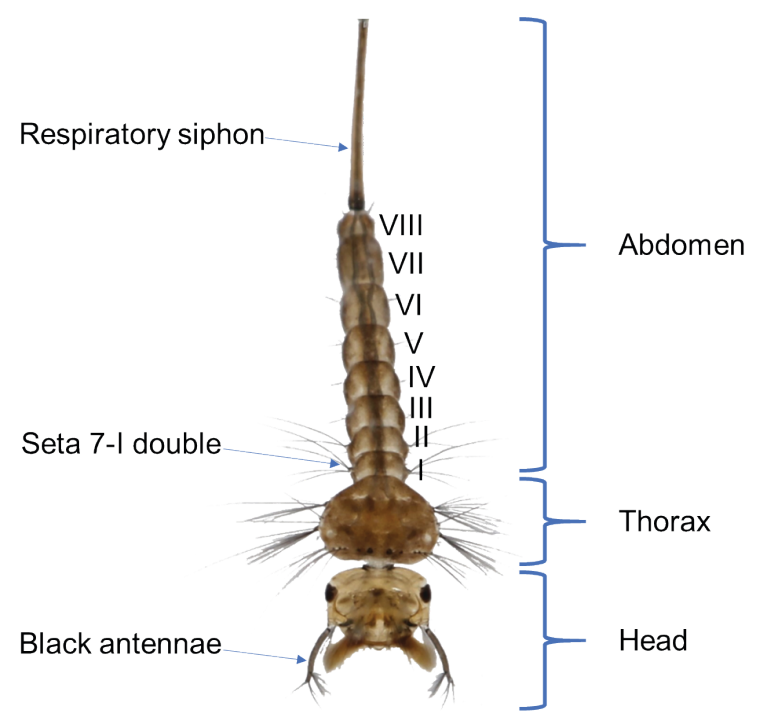

Figure 4. Fourth instar larva of Culex cedecei. Credits: Kristin Sloyer, UF/IFAS

\section{Pupae}

As with other mosquitoes, Culex cedecei pupae are shaped like a comma (Figure 6), are commonly referred to as 'tumblers', and are a non-feeding life stage. The pupae have primarily been described as Culex opisthopus (now Culex taeniopus) from the Caribbean, but both species are similar, and characters have been compared to a Florida laboratory colony. Mosquito pupae breathe through paired appendages on the cephalothorax called 'respiratory trumpets' (Figure 6). In Culex cedecei the respiratory trumpets are long and slender, about 9-10 times as long as wide, but not more than 12 times the length of greatest width. Setae 1,2, and 3 of the cephalothorax (fused head and thorax) are triple, with seta 1 being the longest of the three. On the metanotum (dorsal, sclerotized integument of the $3^{\text {rd }}$ thoracic segment), seta 10 is double. Seta 8 is located in the posterior and lateral corner of segment VIII (Darsie, 2005). Paddle seta 8 is much shorter than one-third the length of the paddle. The posterior and lateral corners of segment VIII are gently rounded. The distal border of the pinna (the part of the trumpet from the apex to the longitudinal axis at the proximal margin of the spiracular opening) is truncate or slightly evaginated, never with a notch (Foote, 1954).

\section{Adult Females}

The adult female of Culex cedecei is a small to mediumsized mosquito with a dark integument (Figure 7). As with other members of the subgenus Melanoconion of Culex, it does not have middorsal acrostichal (bristles on the mesothorax) setae on the scutum. Unlike most other Melanoconion species in Florida, Culex cedecei lacks broad, appressed scales on the vertex and along the ocular line of the head, and instead has numerous narrow appressed scales medially. On the pleuron of the thorax, patches of pale scales occur on the upper mesokatepisternum (the largest, rectangular-shaped sclerite located on the lateral section of the thorax - see Figure 7 for exact location) (seven or more scales) and near the border of the mesepimeron (sclerite located in the anterior part of the thorax - see Figure 7 for location) and mid-coxa. The mesepimeron is scaleless but has a distinct semi-circular area of pale integument beginning at the mesokatepisternum and not usually extending across the entire sclerite (Figure 7). The legs of Culex cedecei are dark scaled, however the hind tarsi possess very narrow indistinct bands of pale scales (Figure 7). These pale bands are typically difficult to observe in lateral view but are visible when the tarsi are viewed from the dorsal perspective.

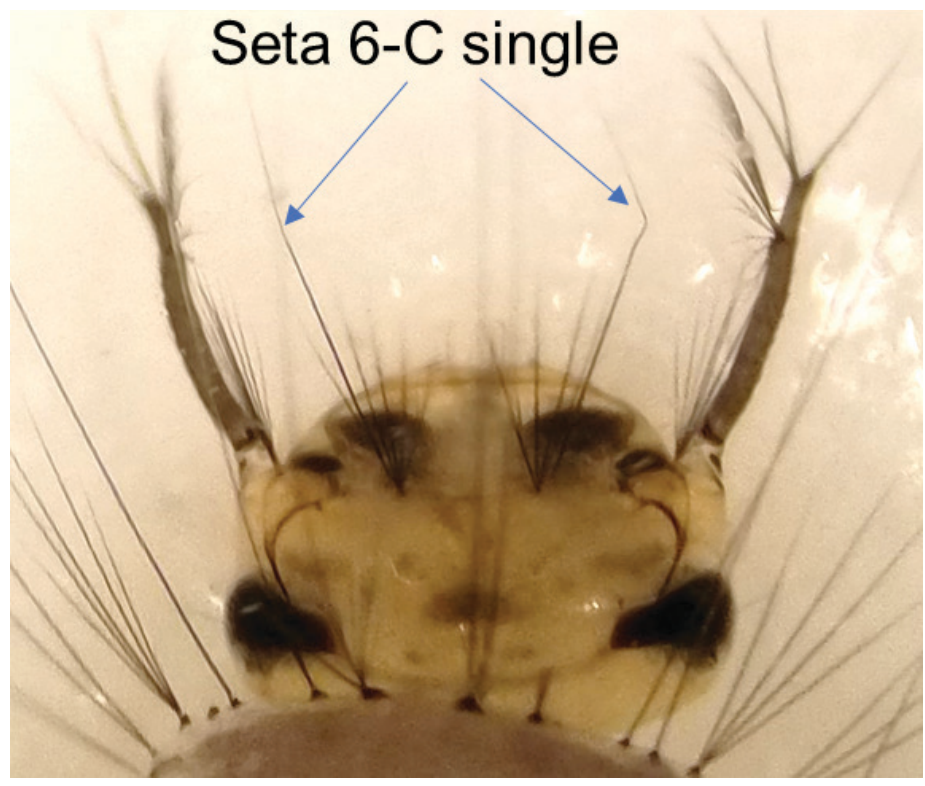

Figure 5. Head of Culex cedecei larva showing black antennae and setae 6-C single (not branched).

Credits: Kristin Sloyer, UF/IFAS

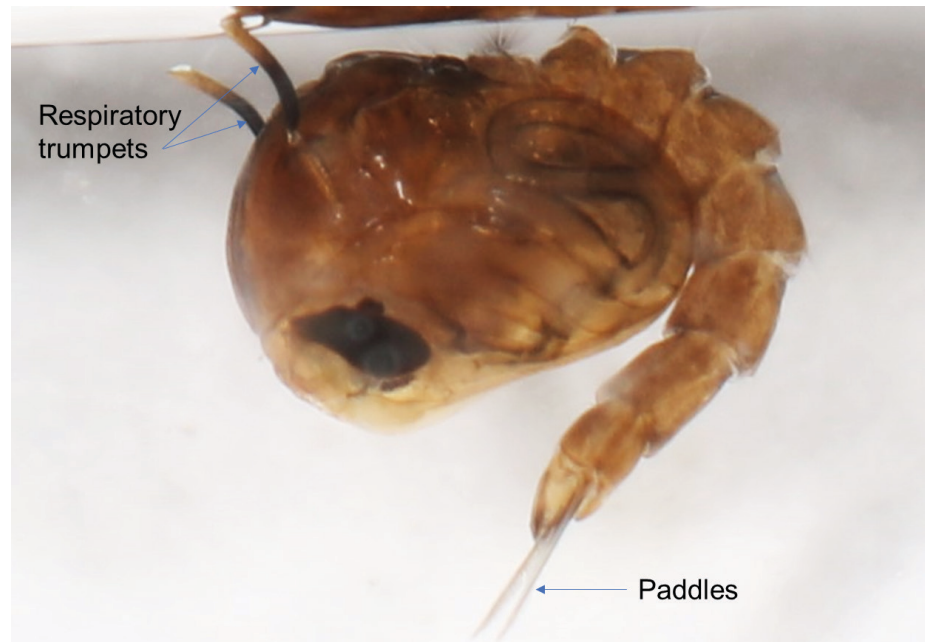

Figure 6. Pupa of Culex cedecei indicating locations of paddles and respiratory trumpets.

Credits: Kristin Sloyer, UF/IFAS 


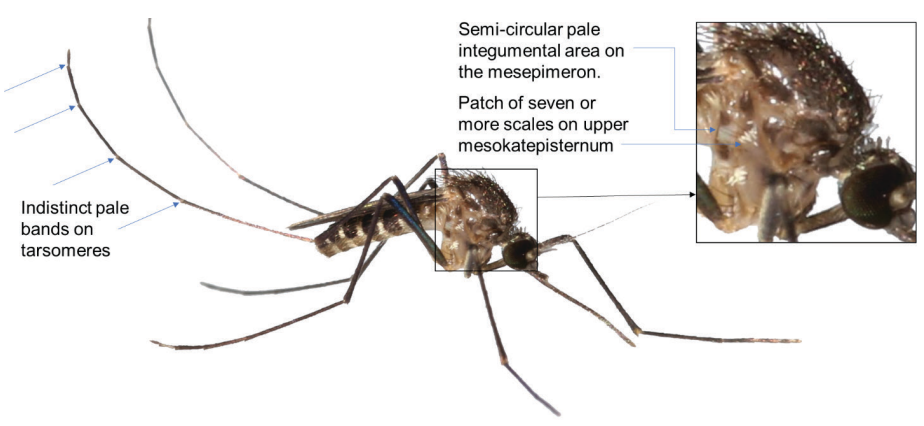

Figure 7. Adult female of Culex cedecei. Inset shows characteristic patches of pale scales and pigmentation on thoracic pleuron. Credits: Kristin Sloyer, UF/IFAS

\section{Adult Males}

The adult males of Culex cedecei share many characters with the female, including the pale integumental area on the mesepimeron, and patch of six or more broad pale scales on the upper mesokatepisternum. As with many male mosquitoes, the palps are longer than the proboscis. Unique among the Melanoconion in Florida, Culex cedecei males have pale-scaled bands at the junctures of palpal segments (Figure 8).

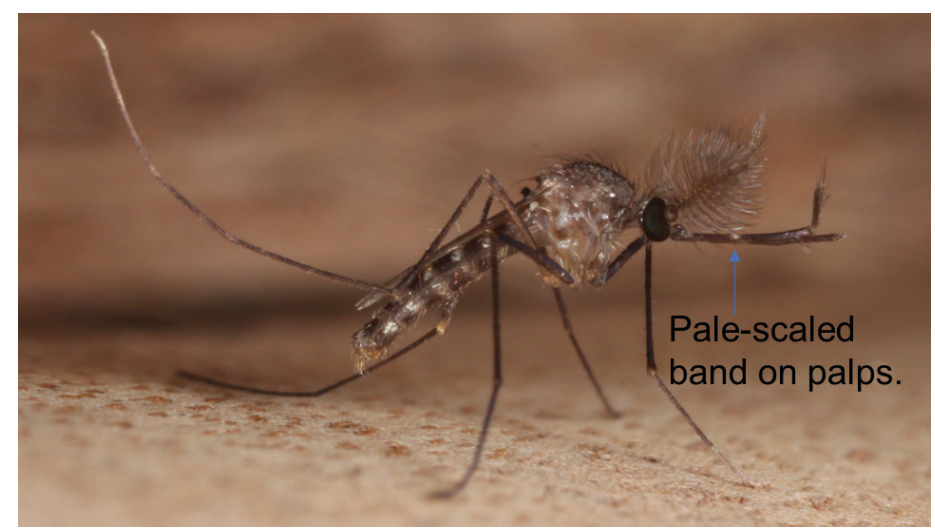

Figure 8. Adult male of Culex cedecei showing pale-scaled band on the palps.

Credits: Nathan Burkett-Cadena, UF/IFAS

\section{Life Cycle}

As with other mosquito species, Culex cedecei are holometabolous and pass through four complete life-stages which include egg, larva, pupa and adult (Figure 9). Culex cedecei egg rafts average 66 eggs per raft (Blosser and Burkett-Cadena 2017) and are laid either directly on the surface of the water or on solid substrate just above the water line (Blosser and Burkett-Cadena 2017) and hatch within two days. Larvae of Culex cedecei are filter-feeders and feed primarily on bacteria and decomposing organic matter. Larvae and pupae obtain atmospheric oxygen from the respiratory siphon and respiratory trumpets, respectively. The pupa is a non-feeding stage and moves vertically though the water using paddles in order to avoid predation. Adults emerge from the pupal stage after approximately three days and sit on top of the water until their exoskeleton sclerotizes. While both adult males and females feed on plant sugars for nutrition, only the adult female takes a blood meal. Culex cedecei is a mammal biting mosquito that will feed upon a wide variety of available mammals, although rats and mice appear to be preferred hosts (Edman 1979, Hoyer et al. 2017). The blood meal is taken to provide protein for the development of eggs, with eggs being laid typically 7-10 days after a blood meal.

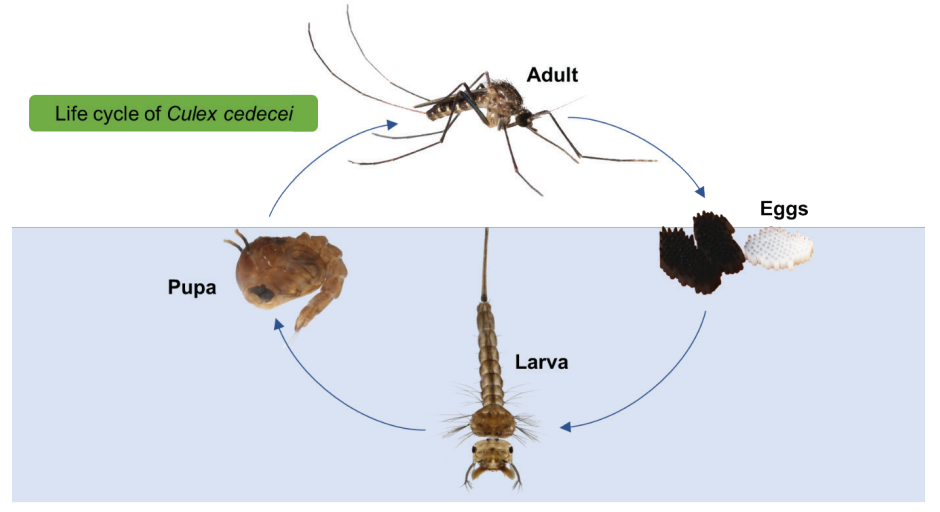

Figure 9. The life cycle of Culex cedecei.

Credits: Kristin Sloyer and Nathan Burkett-Cadena, UF/IFAS

\section{Medical Importance}

Culex cedecei is the primary vector of EVEV due to high infection rates in nature, proclivity for feeding on EVEV vertebrate hosts hispid cotton rat, Sigmodon hispidus, and cotton mouse, Peromyscus gossypinus, and efficient vector competence. Culex cedecei was first implicated as a vector of EVEV when it was found to constitute a large proportion of EVEV-positive mosquito pools from early studies of the virus in the Florida Everglades (Chamberlain et al., 1969). A decade later, Edman (1979) demonstrated that Culex cedecei feeds heavily upon the hispid cotton rat and other rodents, which have been shown to have high EVEV infection rates in nature (Edman, 1974; Edman, 1979; Bigler et al., 1971; Bigler, 1969). Laboratory vector competence studies by Weaver et al. (1986) exposed Culex cedecei to three strains of sympatric subtype II EVEV (Fe4-32bm, Fe5-47et, and $\mathrm{Fe} 3-7 \mathrm{c}$ ) and found that $80 \%$ of females became infected with EVEV and all mosquitoes which became infected with the virus were able to transmit the virus to uninfected hamsters following a 19- to 22-day incubation period (Weaver et al., 1986). Presently, Culex cedecei is the only confirmed natural vector of EVEV, satisfying all four WHO criteria for vector incrimination.

EVEV is maintained in mesic forest environments in south Florida among the cotton rat (S. hispidus), cotton mouse ( $P$. gossypinus), and the primary enzootic vector Culex cedecei (Figure 10). Like other enzootic VEE subtypes, there is no current evidence that humans or equines are hosts in 
the natural transmission cycle of EVEV. Humans, who are thought to rarely develop symptoms from EVEV infection, may become incidental hosts when they enter mesic forest environments in southern Florida and are bitten by Culex cedecei (Aguilar et al., 2011; Ehrenkranz et al., 1970 and 1974; Ventura et al., 1974). Other mammals and birds may be capable of infection with EVEV, although it is not known whether they are competent hosts of the virus.

\section{Everglades virus}

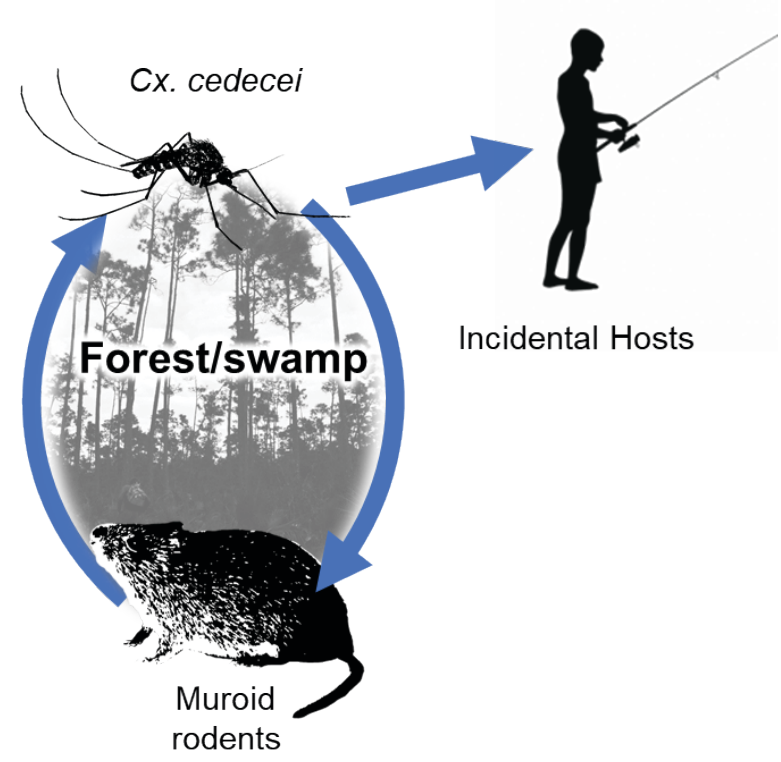

Figure 10. Diagram illustrating enzootic transmission cycle of EVEV and spillover into incidental hosts (humans).

Credits: Kristin Sloyer and Nathan Burkett-Cadena, UF/IFAS

\section{Management}

Culex cedecei is not considered a biting nuisance of humans, because it is uncommon in developed areas and is not considered an aggressive biter, so it is not regularly targeted by mosquito control programs. However, since Culex cedecei transmits EVEV it therefore is a concern for zoonotic disease spillover into human populations. Culex cedecei has been known to infrequently bite humans that venture into its environment (Hoyer et al., 2019), and is likely responsible for transmission of EVEV to humans. It is therefore advisable for people who are visiting sylvatic areas with potentially large Culex cedecei populations (the Florida Everglades ecosystem) to wear protective clothing which covers skin and apply DEET-based or other EPA-registered mosquito repellants, to reduce risk of mosquito bites and transmission of EVEV. For more information on the general control and management of mosquitoes please visit https:// edis.ifas.ufl.edu/in1045.

\section{Selected References}

Aguilar PV, Estrada-Franco JG, Navarro-Lopez R, Ferro C, Haddow AD, Weaver SC. 2011. Endemic Venezuelan equine encephalitis in the Americas: Hidden under the dengue umbrella. Future Virology 6(6): 721-740.

Bigler WJ. 1969. Venezuelan encephalitis antibody studies in certain Florida wildlife. Journal of Wildlife Disease 5:267-270.

Bigler WJ. 1971. Serologic evidence of Venezuelan equine encephalitis virus infections in raccoons of south central Florida. Journal of Wildlife Disease 7:166-170.

Blosser EM. and N.D. Burkett-Cadena. 2017. Culex (Melanoconion) panocossa from peninsular Florida, USA. Acta tropica 167:59-63.

Chamberlain RW, Sudia WD, Work TH, Coleman PH, Newhouse VF, Johnson JG. 1969. Arbovirus studies in south Florida, with emphasis on Venezuelan equine encephalomyelitis virus. American Journal of Epidemiology 89(3):197-210.

Darsie RF, Morris CD. 2003. Keys to the adult females and fourth instar larvae of the mosquitoes of Florida (Diptera: Culicidae). Technical Bulletin of the Florida Mosquito Control Association 1:1-159.

Darsie RF. 2005. Key to the pupae of the mosquitoes (Diptera: Culicidae) of Florida. Proceedings of the Entomological Society of Washington 107(4): 892-902.

Darsie RF, Ward RA. 2005. Identification and geographical distribution of the mosquitoes, North of Mexico. University of Florida Press Gainesville, FL.

Dziem GM, Cupp EW. 1983. Laboratory bionomics of Culex (Melanoconion) taeniopus. Mosquito News 43(2): 170-175.

Edman JD. 1974. Host-feeding patterns of Florida mosquitoes III. Culex (Culex) and Culex (Neoculex). Mosquito News 11(1):95-104.

Edman JD. 1979. Host-feeding patterns of Florida mosquitoes (Diptera: Culicidae) VI. Culex (Melanoconion). Journal of Medical Entomology 15(5-6):521-525.

Ehrenkranz NJ, Ventura AK. 1974. Venezuelan equine encephalitis virus infection in man. Annual Review of Entomology 25:9-14. 
Ehrenkranz NJ. 1970. The natural occurrence of Venezuelan equine encephalitis in the United States. The New England Journal of Medicine 282:298-302.

Foote RH. 1954. The larvae and pupae of the mosquitoes belonging to the Culex subgenera Melanoconion and Mochlostyrax. Technical Bulletin No. 1091, United States Department of Agriculture.

Hoyer IJ, Blosser EM, Acevedo C, Thompson AC, Reeves LE, Burkett-Cadena ND. 2017. Mammal decline, linked to invasive Burmese python, shifts host use of vector mosquitoes towards reservoir hosts of a zoonotic disease. Biology Letters 13: 20170353.

Hoyer IJ, Acevedo C, Wiggins K, Alto B, Burkett-Cadena ND. 2019. Patterns of abundance, host-use, and Everglades virus infection in Culex (Melanoconion) cedecei mosquitoes, Florida, USA. Emerging Infectious Disease 25(6):1093-1100.

Pratt HD, Wirth WW, Denning DG. 1945. The occurrence of Culex opisthopus Komp in Puerto Rico and Florida, with a description of the larva (Diptera, Culicidae). Proceedings of the Entomological Society of Washington 28(1): 39-41.

Sallum MA, Forattini OP, 1996. Revision of the Spissipes section of Culex (Melanoconion) (Diptera: Culicidae). Journal of the American Mosquito Control Association 12(3):517-600.

Sirivanakarn S, Belkin JN. 1980. The identity of Culex (Melanoconion) taeniopus Dyar and Knab and related species with notes on the synonymy and description of a new species (Diptera: Culicidae). Mosquito Systematics 12(1): 7-24.

Stone A, Hair JA. 1968. A new Culex (Melanoconion) from Florida (Diptera: Culicidae). Mosquito News 28(1):39-41.

Ventura EK, Buff EE, Ehrenkranz NJ. 1974. Human Venezuelan equine encephalitis virus infection in Florida. American Journal of Tropical Medicine and Hygiene 23: 507-512.

Weaver SC, Sherer WF, Taylor CA, Castello DA, Cupp EW. 1986. Laboratory vector competence of Culex (Melanoconion) cedecei for sympatric and allopatric Venezuelan equine encephalomyelitis viruses. American Journal of Tropical Medicine and Hygiene 35: 619-623.
West RG, Mathias DR, Day JF, Boohene CK, Unnasch TR, Burkett-Cadena ND. 2020. Vectorial capacity of Culiseta melanura (Diptera: Culicidae) changes seasonally and is related to epizootic transmission of Eastern Equine Encephalitis Virus in Central Florida. Frontiers in Ecology and Evolution, 8:270. 